\title{
ESTIMATION OF THE EFFECT OF CHANGES IN FOREST ASSOCIATIONS ON RUNOFF PROCESSES IN BASINS: CASE STUDY IN THE HRON AND TOPLA RIVER BASINS
}

\author{
Peter RONČÁK ${ }^{1 *}$, Kamila HLAVČOVÁ ${ }^{1}$, Tamara LÁTKOVÁ ${ }^{1}$
}

\section{Abstract}

Distributed rainfall-runoff model simulations are often used to evaluate the impact of changes on the generation of runoff. These models have the advantage of reflecting the effects of land use on spatially distributed model parameters. The article deals with changes in forest associations as a result of global climate changes. In this article the WetSpa model was used for estimating the impact of forest changes on the runoff regime in the Hron and Topla river basins, with an emphasis on the parameterization of the land cover properties in the runoff simulations. The parameters of the model were estimated using climate data and three digital map layers: a land-use map, soil map and digital elevation model. This work contains two land use change scenarios of forest associations and also two scenarios of global climate change. Both types of scenarios of changes were prepared, and the runoff under the new conditions was simulated.
Address

1 Department of Land and Water Resources Management, Faculty of Civil Engineering, Slovak University of Technology, Radlinskeho 11, 81368 Bratislava, Slovak Republic.

* Corresponding author: peter.roncak@stuba.sk

\section{Key words}

- Distributed rainfall-runoff model,

- Land use and climate change scenarios,

- Changes in runoff.

\section{INTRODUCTION}

The effects of land use and climate change on hydrology have been an important area of research in recent decades, particularly with respect to the generation of runoff. Land use directly impacts key aspects of hydrological processes, such as evapotranspiration, infiltration and runoff. Observational evidence indicates with a high degree of confidence that climate change affects hydrological systems (Rosenzweig et al., 2007; Blahušiaková et al., 2015).). One of the recent topics in hydrological modelling is the assessment of the effects of land use changes on water resources (Lui and De Smedt, 2005). Runoff and its resulting impacts have become more significant and have increased along with local economic developments. As a watershed becomes more developed, it also becomes more hydrologically active with changing runoff components, streamflows and flood volumes. The effect of land use on the generation of storm runoff is very complicated. Land use and soil cover have an effect on interception, surface retention, evapotranspiration, and resistance to overland flow (Olivera and Maidment, 1999).

Hydrological models have been widely used to study many practical and pressing issues that arise during the planning, design, operation, and management of water resources systems (Lin et al., 2007) and also to quantify the impacts of land use and climate change on the hydrological cycle (Lin et al., 2010). Rainfall-runoff models are often used as a tool to assess the effects of climate change and land use on the hydrological cycle. While the modeling of climate change is mainly performed using conceptual rainfall-runoff models, the simulation of the impact of land use changes on the generation of runoff calls for models with spatially distributed parameters. In order to simulate runoff in terms of changes in land use or climate change, rainfall-runoff models with spatially distributed parameters, such as, for example, the Wasim model, Topmodel (Kostka and Holko, 2001; Holko et al., 2014), WetSpa (Poórová et al., 2005) and (Hlavčová et al., 2005; Rončák and Hlavčová, K. (2015), are used in Central Europe. 
The main aim of the article is to estimate the effect of changes in forest associations as a result of climate change on runoff processes in the Topl'a and Hron River basins. We used two land use scenarios with forest associations for the 2075 horizon and two global climate change scenarios with horizons of 2025, 2055 and 2085. In this paper we also looked at the model's sensitivity to input data. The model was calibrated for two periods (1981 - 1995 and 2007 - 2010). We assumed that the period 2007-2010 would be similar in terms of the average daily values for the air temperature and daily precipitation totals.

\section{METHODOLOGY}

Land use scenarios were created for the entire territory of the Slovak Republic (Škvarenina et al., 1996) by the Technical University of Zvolen and published in the Landscape Atlas of the Slovak Republic (Mind'aš and Škvarenina, 2002). Subsequently, the ArcGIS program was used to process and categorize the data for the needs of the WetSpa rainfall-runoff model. The Dutch KNMI (with an A1B emission scenario) and German MPI (with an A1B emission scenario) climate scenarios were used for this research. These regional circulation models are based on the German ECHAM5 GCM boundary conditions and the SRES-A1B (moderate) emission scenario. Both models are coupled, i.e., atmosphere-ocean circulation models with greenhouse gases and aerosols influence changes in radiative forcing (Lapin et al., 2012).

\subsection{The rainfall-runoff model}

To simulate the flow, the physically-based WetSpa rainfall-runoff model was used. The model uses geospatially referenced data as the input for deriving the model's parameters, which include most data types supported by ArcGIS, such as coverage, shape files, grids and ASCII files. An image can be used for a reference within a view, but is not used directly by the model. Digital maps of the topography, land use and soil types are the 3 base maps used in the model, while other digital data are optional, depending upon the data available, the purpose, and the accuracy requirements of the project (Wang et al., 1996).

The calibration of the model requires the identification of a set of global parameters which will provide the best possible agreement between the measured and simulated parameters of the hydrological model in accordance with the selected criteria. Various agreement criteria were used during the calibration of the models for expressing any differences between the observed and modelled data. The calibration period was from $1981-1995$ and 2007 - 2010. Twelve parameters for which a range of admissible values set were optimized. The Nash - Sutcliffe coefficient was chosen as the dominant criterion in this work.

\section{DATA}

For simulations of runoff and other components of hydrological balance under changed conditions, the WetSpa distributed rainfall-runoff model was used. This research was made for 9 selected basins in Slovakia. For this paper only the Topl'a and Hron catchments were chosen as examples.

The Topla is a river in eastern Slovakia which is the right tributary of the Ondava River. It rises in the Lubovnianska highlands. The Topl'a catchment $(1062.24 \mathrm{~km} 2)$ is situated in eastern Slovakia (Fig. 1). The catchment is in a flysch mountain area of Nizke Beskydy on Slovakia's border with Poland; it is characterised by numerous springs, bogs and streams. Prolonged rainfall has a great influence on the runoff regime, especially during the growing season and periods of melting snow. The climate is warm and moderately humid with cool winters. The average precipitation amounts to about 700 - $800 \mathrm{~mm}$ per year (Lapin et al., 2002). The potential natural vegetation is characterized by submontane beech forests in the north, while the lowlands are covered by Carpathian oak-hornbeam forests (Maglocký, 2002). Input data in a daily step in the period between 1 January 1981 and 31 December 2010 was used in this study. The following hydro-meteorological data were used in the model: daily

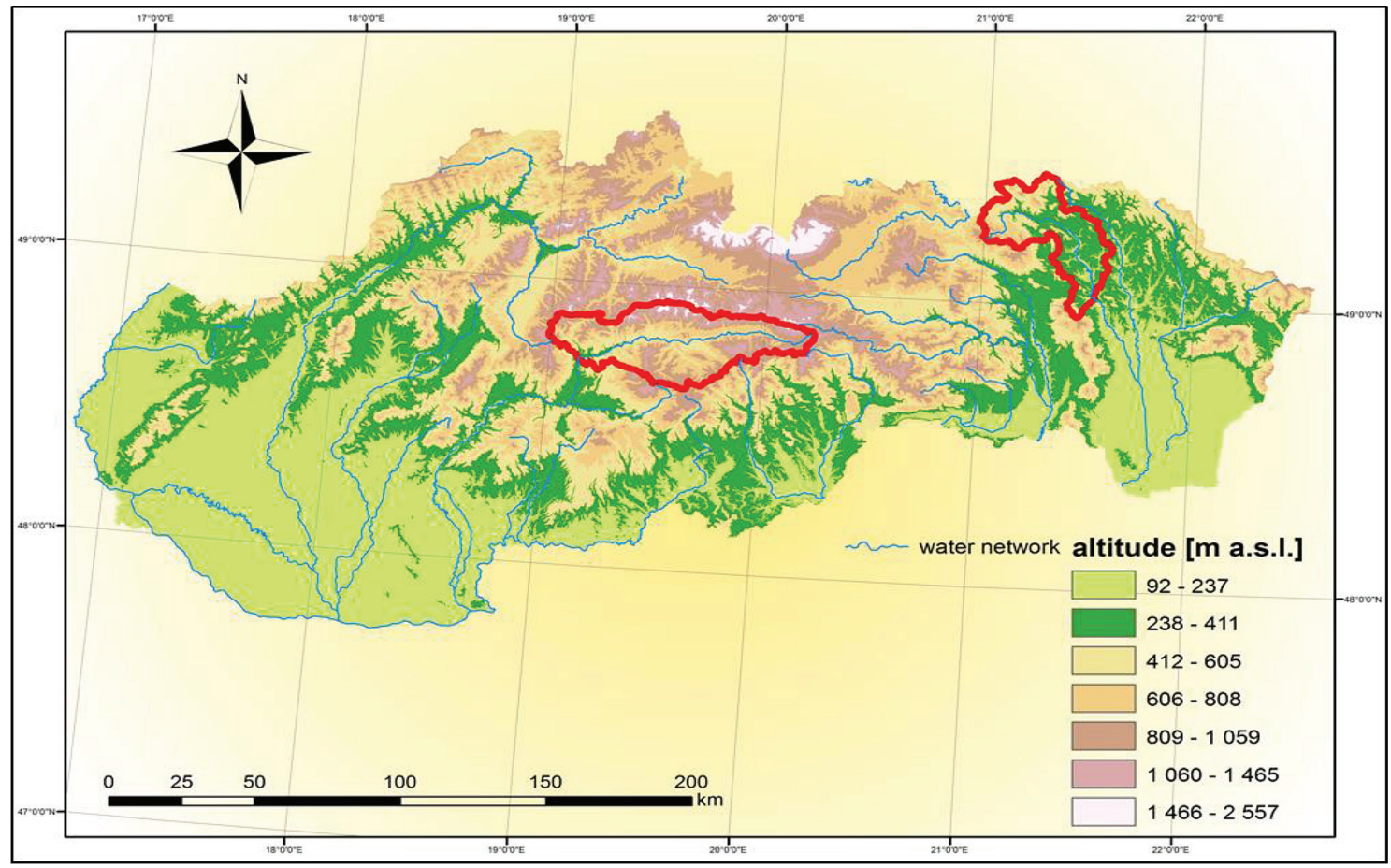

Fig. 1: Location of the Hron and Topla River basins. 
Tab. 1: Values of global WetSpa model parameters and the NS coefficient for two calibration periods.

\begin{tabular}{|c|c|c|c|c|c|c|c|c|c|c|c|c|c|c|}
\hline \multirow{2}{*}{$\begin{array}{l}\text { river } \\
\text { basin }\end{array}$} & \multirow{2}{*}{$\begin{array}{l}\text { calibration } \\
\text { period }\end{array}$} & \multirow{2}{*}{ NS coef. } & \multicolumn{12}{|c|}{ Global parameters } \\
\hline & & & $\mathrm{ki}$ & $\mathrm{kg}$ & k_ss & k_ep & $\mathrm{G}_{0}$ & $\mathrm{G}_{\max }$ & $\mathrm{k} \_$imp & $\mathrm{T}_{0}$ & k_snow & k_rain & $\mathrm{K}_{-}$run & $\mathrm{P}_{\text {max }}$ \\
\hline \multirow{2}{*}{ Topl'a } & 1981-1995 & 0.669 & 7.38 & 7.74 & 1.01 & 1.09 & 68.9 & 247.3 & 0.12 & 0.66 & 2.3 & 0.36 & 16.22 & 108 \\
\hline & $2007-2010$ & 0.755 & 9.33 & 8.88 & 0.49 & 0.292 & 61.4 & 238.8 & 0.175 & 0.16 & 2.182 & 0.026 & 18.553 & 116 \\
\hline \multirow{2}{*}{ Hron } & 1981-1995 & 0.771 & 2.58 & 8.32 & 0.91 & 0.94 & 48 & 240.7 & 0.884 & 0.03 & 2.781 & 0.17 & 16.522 & 108 \\
\hline & $2007-2010$ & 0.664 & 1.9 & 5 & 0.8 & 0.6 & 62 & 239 & 0.4 & 0.2 & 2.1 & 0.2 & 16 & 118 \\
\hline
\end{tabular}

Tab. 2: Long-term mean monthly values of the air temperatures and precipitation for the reference period and their changes in the future time horizons in the Topl'a River basin.

\begin{tabular}{|c|c|c|c|c|c|c|c|c|c|c|c|c|c|c|}
\hline \multicolumn{3}{|c|}{ temperature $\left[{ }^{\circ} \mathrm{C}\right]$} & I & II & III & IV & $\mathrm{V}$ & VI & VII & VIII & IX & $\mathrm{X}$ & $\mathrm{XI}$ & XII \\
\hline \multirow{7}{*}{ Topl'a } & \multicolumn{2}{|c|}{$1981-2010$} & -4.6 & -3.6 & 0.3 & 5.6 & 10.9 & 13.8 & 15.7 & 14.9 & 10.6 & 6.1 & 1.1 & -3.4 \\
\hline & \multirow{3}{*}{ KNMI } & 2025 & 0.8 & 2.2 & 2.6 & 2.6 & 2.9 & 3.0 & 2.8 & 2.8 & 2.8 & 3.0 & 1.7 & 0.8 \\
\hline & & 2055 & 2.0 & 4.1 & 3.2 & 3.3 & 3.7 & 4.0 & 3.9 & 3.7 & 3.3 & 3.5 & 2.7 & 2.6 \\
\hline & & 2085 & 3.5 & 4.1 & 4.2 & 4.0 & 4.8 & 5.4 & 5.7 & 5.1 & 4.1 & 4.5 & 4.4 & 4.2 \\
\hline & \multirow{3}{*}{ MPI } & 2025 & 0.9 & 2.1 & 2.0 & 2.4 & 2.7 & 2.9 & 2.6 & 2.8 & 2.8 & 3.0 & 2.1 & 0.9 \\
\hline & & 2055 & 2.5 & 4.3 & 3.2 & 3.2 & 3.5 & 3.4 & 3.5 & 3.9 & 3.5 & 3.4 & 3.0 & 2.4 \\
\hline & & 2085 & 3.8 & 4.7 & 4.1 & 3.7 & 4.3 & 4.9 & 4.9 & 5.2 & 4.9 & 4.8 & 4.6 & 4.3 \\
\hline \multicolumn{3}{|c|}{ precipitation $[\mathrm{mm}]$} & I & II & III & IV & V & VI & VII & VIII & IX & $\mathrm{X}$ & $\mathrm{XI}$ & XII \\
\hline \multirow{7}{*}{ Topl'a } & \multicolumn{2}{|c|}{$1981-2010$} & 35.8 & 33.8 & 33.5 & 51.7 & 84.1 & 96.4 & 96.1 & 74.9 & 64.1 & 44.1 & 38.1 & 43.0 \\
\hline & \multirow{3}{*}{ KNMI } & 2025 & -8.4 & -0.7 & -4.4 & -7.8 & -6.0 & 6.1 & -3.5 & -0.5 & 27.9 & 1.7 & 2.4 & 3.1 \\
\hline & & 2055 & -1.0 & -0.2 & 4.6 & 12.4 & -6.0 & 2.5 & -9.0 & -6.1 & 14.7 & 10.4 & -2.0 & 15.3 \\
\hline & & 2085 & 7.3 & 11.5 & 11.4 & 7.9 & -13.4 & -25.6 & -19.6 & 0.9 & 50.8 & 10.9 & 4.6 & 17.8 \\
\hline & \multirow{3}{*}{ MPI } & 2025 & -1.3 & 9.2 & -2.1 & -5.6 & -1.2 & 12.7 & -4.9 & 12.9 & 6.9 & 1.4 & 1.3 & 1.3 \\
\hline & & 2055 & 4.7 & 0.2 & 11.4 & 12.9 & -8.6 & 10.3 & -0.3 & 10.7 & 16.1 & 13.1 & -2.1 & 10.2 \\
\hline & & 2085 & 13.3 & 10.2 & 12.6 & 10.8 & -2.1 & -15.9 & -19.7 & 5.6 & 12.5 & 9.5 & 4.9 & 8.2 \\
\hline
\end{tabular}

Tab. 3: Long-term mean monthly values of air temperatures and precipitation of reference period and their changes for the future time horizons in the Hron River basin.

\begin{tabular}{|c|c|c|c|c|c|c|c|c|c|c|c|c|c|c|}
\hline \multicolumn{3}{|c|}{ temperature $\left[{ }^{\circ} \mathrm{C}\right]$} & I & II & III & IV & V & VI & VII & VIII & IX & $\mathrm{X}$ & XI & XII \\
\hline \multirow{7}{*}{ Topl'a } & \multicolumn{2}{|c|}{$1981-2010$} & -4.1 & -3.1 & 0.5 & 5.9 & 11.1 & 14.0 & 16.0 & 15.4 & 11.0 & 6.4 & 1.1 & -3.1 \\
\hline & \multirow{3}{*}{ KNMI } & 2025 & 0.0 & 0.8 & 1.0 & 0.4 & 0.9 & 0.9 & 0.9 & 0.9 & 0.9 & 1.6 & 0.5 & 0.1 \\
\hline & & 2055 & 1.3 & 2.6 & 1.4 & 1.0 & 1.6 & 2.0 & 1.9 & 1.9 & 1.5 & 2.0 & 1.5 & 1.8 \\
\hline & & 2085 & 2.8 & 2.8 & 2.3 & 1.7 & 2.7 & 3.5 & 3.7 & 3.3 & 2.4 & 3.0 & 3.1 & 3.4 \\
\hline & \multirow{3}{*}{ MPI } & 2025 & 0.1 & 0.8 & 0.4 & 0.1 & 0.6 & 0.7 & 0.6 & 1.0 & 0.9 & 1.5 & 0.9 & 0.3 \\
\hline & & 2055 & 1.9 & 2.9 & 1.3 & 0.7 & 1.3 & 1.3 & 1.5 & 2.2 & 1.7 & 1.9 & 1.9 & 1.6 \\
\hline & & 2085 & 3.3 & 3.4 & 2.0 & 1.4 & 2.1 & 2.9 & 2.8 & 3.5 & 3.2 & 3.2 & 3.3 & 3.4 \\
\hline \multicolumn{3}{|c|}{ precipitation $[\mathrm{mm}]$} & I & II & III & IV & V & VI & VII & VIII & IX & $\mathrm{X}$ & XI & XII \\
\hline \multirow{7}{*}{ Topl'a } & \multicolumn{2}{|c|}{$1981-2010$} & 48.2 & 45.1 & 53.6 & 56.1 & 94.0 & 101.3 & 93.7 & 82.2 & 66.0 & 59.3 & 67.3 & 62.6 \\
\hline & \multirow{3}{*}{ KNMI } & 2025 & -3.1 & 3.4 & 0.4 & -4.2 & -9.2 & 0.8 & -11.4 & 3.9 & 34.3 & -2.1 & 4.2 & 20.4 \\
\hline & & 2055 & 5.2 & 8.8 & 11.7 & 16.4 & -0.6 & -15.7 & -9.5 & 2.9 & 19.4 & 8.5 & 2.5 & 19.9 \\
\hline & & 2085 & 14.1 & 21.8 & 24.9 & 10.3 & -19.9 & -32.9 & -22.1 & -3.1 & 37.7 & 14.6 & 6.8 & 24.1 \\
\hline & \multirow{3}{*}{ MPI } & 2025 & -0.7 & 8.8 & 3.4 & -3.6 & -8.4 & 19.7 & 9.5 & -3.3 & 25.1 & -3.9 & 8.5 & 13.1 \\
\hline & & 2055 & 7.8 & 6.8 & 16.7 & 21.8 & -10.5 & 7.8 & -3.7 & -8.3 & 16.4 & 7.8 & 1.6 & 17.1 \\
\hline & & 2085 & 15.5 & 18.1 & 26.2 & 18.3 & -14.7 & 0.1 & -10.1 & -3.8 & 30.3 & 18.6 & 13.9 & 14.8 \\
\hline
\end{tabular}


precipitation totals from spot measurements at 15 stations and the average daily values for the air temperature at 4 climatological stations. The flow data consisted of the average daily flows at the Topla - Hanušovce nad Topl'ou profile.

As the second pilot basin for the case study, we used the Upper Hron River catchment (the catchment outlet at the city of Banská Bystrica) with an area of $1775.30 \mathrm{~km}^{2}$ and an altitude ranging from 340 to 2043 m.a.s.1. (the average altitude is 805 m.a.s.1.). The average annual precipitation rate for the whole catchment is $800 \mathrm{~mm}$, while in the lower parts of the catchment it is $600 \mathrm{~mm}$ and goes up to 1600 $\mathrm{mm}$ in the upper parts. The average annual evapotranspiration ranges from 300 to $600 \mathrm{~mm}$. Input data in a daily step in the period between 1 January 1981 and 31 December 2010 was used in this study. The input data consisted of average daily flows in the river Hron - Banská Bystrica section, average daily temperatures from 5 stations, and average daily precipitation rates from 15 stations.

Tables 2 and 3 illustrate the long-term mean monthly values of the air temperatures and precipitation for the reference period 19812010 in the Topla and Hron River basins and their changes for the three future time horizons according to the KNMI and MPI regional climate change scenarios.

\section{RESULTS AND DISCUSSION}

\subsection{Impact of land use changes on runoff}

The use of water by forested land is generally greater than that of other land-use types and leads to reduced flows from river basins. This is mainly caused by higher evapotranspiration. Although forests have an obvious influence on flood events for small-scale catchments, the effects of forests on flood events are likely to be minimal for large-scale catchments (Calder, 2007). In the simulation, the expected parameters of the model were obtained from a model calibration in the period 1981-1995. For the reference period, 1981-2010 was selected. The simulated long-term mean monthly discharges were compared with the long-term mean monthly discharges of the reference period.

The current land use in the Topl'a River basin (Fig. 2) indicates that the cropland amounts to $22 \%$ and the short grass $17 \%$. The three types of forests have the following descriptions: coniferous trees $(6 \%)$, deciduous trees $(43 \%)$ and mixed forests $(6 \%)$. The other classes have small or insignificant values. Deciduous forests occupy the largest area of the basin area. In the first scenario cropland $(15 \%)$ and short grass $(20 \%)$ also predominate. The components of the forests are deciduous trees $(60 \%)$ and mixed forests $(1 \%)$. The deciduous forest increased in the first scenario in comparison with a)

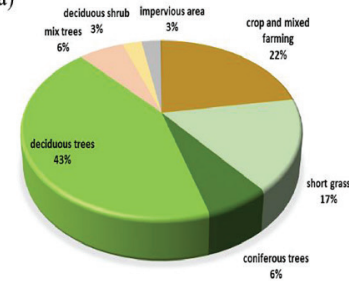

b)

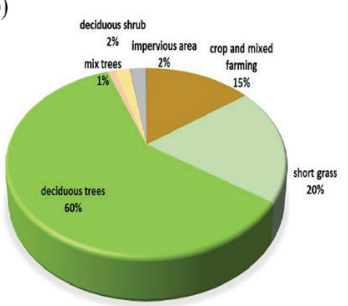

c)

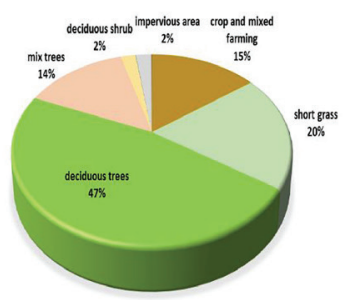

Fig. 2: Current land use and land use change scenarios in the Topla - Humenne basin: a) current land use, b) 1st land use change scenario, c) 2nd land use change scenario

a)

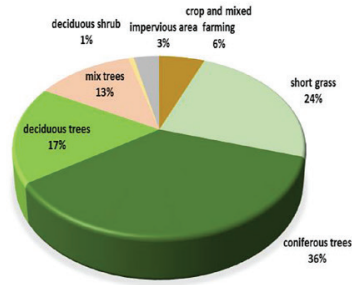

b)
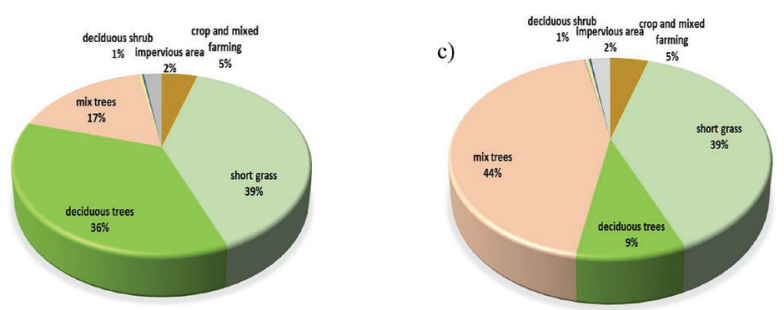

Fig. 4: Current land use and land use change scenarios in the Hron - Banska Bystrica basin: a) current land use, b) 1st land use change scenario, c) 2nd land use change scenario

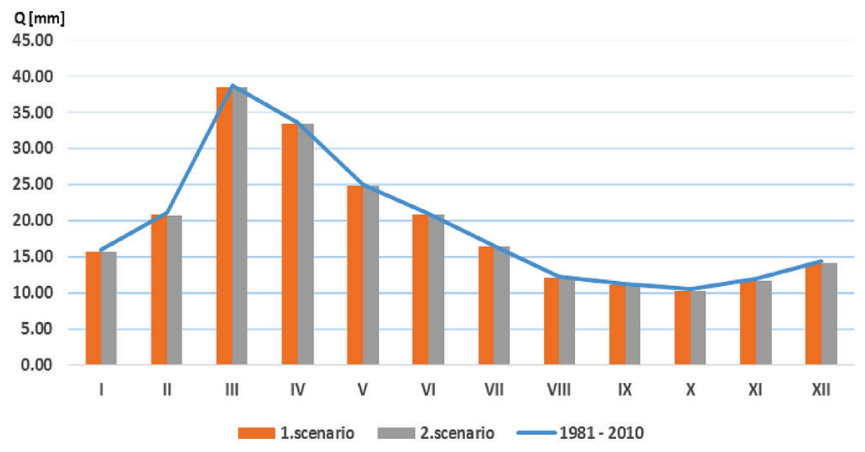

Fig. 3: Comparison of the long-term mean monthly runoff in the Topla River basin between the land use scenarios and the current state

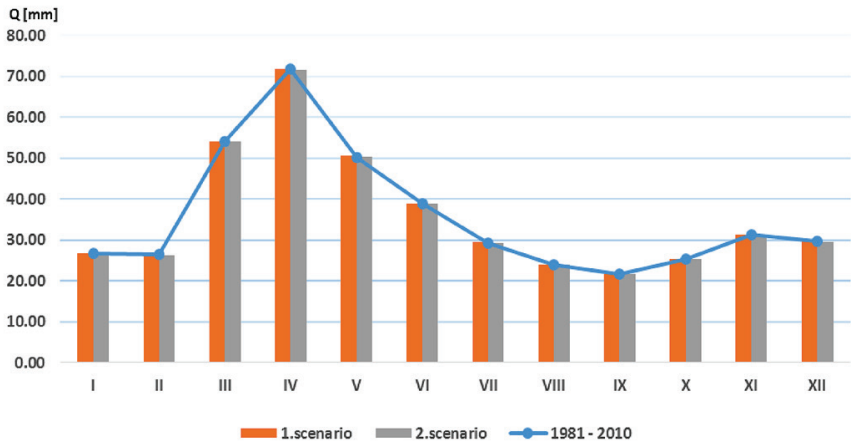

Fig. 5: Comparison of the long-term mean monthly runoff in the Hron River basin between the land use scenarios and the current state 
its current state. This change in forest composition has an impact on higher evapotranspiration and a smaller degree of interception and runoff. In the second scenario cropland (15\%) and short grass (20\%) predominate. In comparison with the previous scenario, the deciduous trees amount to $47 \%$, and the tree mix has increased to $14 \%$. Some differences in the forest composition can be seen between the scenarios and the current state. The deciduous forest should increase; in contrast, the coniferous forest will mainly decrease because of global warming. This component will move to higher altitudes.

It can be seen (Fig. 5) that changes in forest composition do not have a significant impact on monthly discharges. The similar values of the land use parameters, especially root depth and interception, are not different to a great extent. These can significantly affect the runoff on a catchment.

The total area of afforestation on the Hron River basin (Fig. 4) near the Banská Bystrica gauging station is $66 \%$. According to the current land use, deciduous forest occupies an area of $17 \%$, coniferous forest $36 \%$, and mixed forests $13 \%$. The cropland has a value of approximately $6 \%$. The grassy area classified in the model as short grass occupies an area of around $24 \%$ in this basin. This river basin is characterized by a high percentage of forest coverage, i.e., two thirds of the basin are covered with forests. Relatively significant changes in the forest in this river basin are therefore visible. Because of the impact of increasing temperatures, coniferous forests will disappear. In the first scenario deciduous forest will comprise around one-third of the area; short grass will also comprise one third. Deciduous forest is expected to amount to $17 \%$. In the second scenario, the situation will change. The share of land use in the sub-basin of the river Hron will increase; as it will be devoted to mixed forests, it will occupy almost half of the area. On the contrary, deciduous forests will reach just $9 \%$. The representation of deciduous forests compared to the actual scenarios, especially in the first scenario, will markedly decrease. The growth of short grass will also be noticeable. The values of the categories will not change significantly. The percentages of the occurrence of the current land use and expected future land use will remain similar.

The long-term mean monthly runoff (Fig. 3) will increase, especially during the period from the spring to late summer months in the Hron River basin. Of course, the difference in the values of the runoff will remain very small; it will only be a difference in decimals.

\subsection{Impact of climate change on runoff}

Based on the MPI climate scenario, the long-term monthly average flow in August will be reduced by $38 \%$. A significant increase may be expected in October. The long-term mean monthly (Tab. 4) runoff in the Topla river basin could increase to $90 \%$, compared to the reference period.

The Hron river basin will manifest an increase in average monthly discharges, especially during the winter months. This will be valid for both scenarios and all horizons (except for the horizon 2025 in the MPI climate scenario). According to the KNMI scenario, the runoff can achieve a $100 \%$ increase in January and February in the last horizon. Due to the climate change, the runoff will react in the opposite way in the summer period. According to the KNMI scenario, the monthly flow will gradually decrease by $2 \%$ up to $40 \%$ in the months of May to August. A similar situation may be expected under the MPI climate scenario; the only difference is visible in the horizon of 2025, where there would be an increase in the runoff compared to the reference period. In the autumn term an increase in runoff in both scenarios may be expected when compared with the values of the runoff in the reference period with the current climate conditions.

Using the global parameters from the calibration period of 2007 -2010, the long-term mean monthly discharge has more extreme values. The sensitivity of the WetSpa model is shown in the input data.

Tab. 4: Simulated long-term mean monthly runoff using the parameters from the 1981 - 1995 calibration period in the Topla River basin and its changes for the 3 future time horizons.

\begin{tabular}{|c|c|c|c|c|c|c|c|c|c|c|c|c|c|}
\hline scenario & horizon & $\mathrm{I}$ & II & III & IV & $\mathrm{V}$ & $\mathrm{VI}$ & VII & VIII & IX & $\mathrm{X}$ & XI & XII \\
\hline \multicolumn{2}{|c|}{$1981-2010[\mathrm{~mm}]$} & 16 & 21 & 39 & 34 & 25 & 21 & 17 & 12 & 11 & 10 & 12 & 14 \\
\hline \multirow{3}{*}{ KNMI [\%] } & 2025 & 8 & 16 & -19 & -26 & -20 & -13 & 35 & 21 & 104 & 79 & 20 & 13 \\
\hline & 2055 & 41 & 46 & -18 & 0 & -5 & 1 & -6 & -9 & 29 & 82 & 9 & 23 \\
\hline & 2085 & 102 & 69 & 4 & 1 & -18 & -33 & -19 & -31 & 68 & 93 & 41 & 82 \\
\hline \multirow{3}{*}{ MPI [\%] } & 2025 & -22 & 17 & -6 & 19 & -7 & 4 & 12 & 35 & 36 & 48 & 14 & -11 \\
\hline & 2055 & 32 & 59 & -6 & 19 & 9 & 6 & -13 & 9 & 64 & 85 & 21 & 28 \\
\hline & 2085 & 54 & 51 & 4 & 11 & 7 & -32 & -38 & -15 & -8 & 41 & 10 & 31 \\
\hline
\end{tabular}

Tab. 5: : Simulated long-term mean monthly runoff using the parameters from the 2007 - 2010 calibration period in the Topla River basin and its changes for the 3 future time horizons.

\begin{tabular}{|c|c|c|c|c|c|c|c|c|c|c|c|c|c|}
\hline scenario & horizon & I & II & III & IV & $\mathrm{V}$ & VI & VII & VIII & IX & $\mathrm{X}$ & XI & XII \\
\hline \multicolumn{2}{|c|}{$1981-2010[\mathrm{~mm}]$} & 17 & 23 & 37 & 31 & 24 & 20 & 16 & 12 & 11 & 10 & 12 & 15 \\
\hline \multirow{3}{*}{ KNMI [\%] } & 2025 & 4 & 8 & -20 & -27 & -21 & -12 & 40 & 23 & 114 & 78 & 17 & 10 \\
\hline & 2055 & 37 & 31 & -16 & 5 & -4 & 3 & -7 & -9 & 36 & 85 & 6 & 23 \\
\hline & 2085 & 90 & 55 & 5 & 6 & -17 & -35 & -18 & -30 & 83 & 96 & 41 & 78 \\
\hline \multirow{3}{*}{ MPI [\%] } & 2025 & -19 & 17 & -3 & 15 & -12 & 5 & 10 & 39 & 38 & 47 & 13 & -13 \\
\hline & 2055 & 34 & 45 & -4 & 25 & 9 & 6 & -17 & 13 & 69 & 85 & 20 & 27 \\
\hline & 2085 & 51 & 42 & 1 & 16 & 9 & -35 & -40 & -11 & -4 & 43 & 10 & 29 \\
\hline
\end{tabular}


Tab. 6: Simulated long-term mean monthly runoff using the parameters from the 1981 - 1995 calibration period in the Hron River basin and its changes for the 3 future time horizons.

\begin{tabular}{|c|c|c|c|c|c|c|c|c|c|c|c|c|c|}
\hline scenario & horizon & I & II & III & IV & $\mathrm{V}$ & VI & VII & VIII & IX & $\mathrm{X}$ & $\mathrm{XI}$ & XII \\
\hline \multicolumn{2}{|c|}{$1981-2010[\mathrm{~mm}]$} & 27 & 26 & 54 & 72 & 50 & 39 & 29 & 24 & 21 & 25 & 31 & 30 \\
\hline \multirow{3}{*}{ KNMI [\%] } & 2025 & 27 & 56 & 2 & -11 & -7 & -19 & -2 & 0 & 42 & 39 & 11 & 26 \\
\hline & 2055 & 77 & 90 & 20 & 0 & 3 & -12 & -26 & -7 & 16 & 41 & 4 & 52 \\
\hline & 2085 & 104 & 112 & 36 & 1 & -23 & -38 & -40 & -40 & 2 & 32 & 28 & 86 \\
\hline \multirow{3}{*}{ MPI [\%] } & 2025 & -22 & -5 & -2 & 27 & 31 & 27 & 43 & 19 & 53 & 42 & 12 & -4 \\
\hline & 2055 & 67 & 95 & 14 & 1 & -5 & -5 & -14 & -26 & -10 & 14 & 4 & 38 \\
\hline & 2085 & 65 & 81 & 24 & 28 & 5 & -8 & -14 & -30 & 1 & 69 & 39 & 62 \\
\hline
\end{tabular}

Tab. 7: Simulated long-term mean monthly runoff using the parameters from the 2007 - 2010 calibration period in the Hron River basin and its changes for the 3 future time horizons.

\begin{tabular}{|c|c|c|c|c|c|c|c|c|c|c|c|c|c|c|}
\hline \multicolumn{2}{|c|}{ scenario } & horizon & I & II & III & IV & V & VI & VII & VIII & IX & X & XI & XII \\
\hline \multicolumn{2}{|c|}{1981 - 2010 [mm] } & 25 & 24 & 46 & 69 & 55 & 42 & 32 & 26 & 22 & 25 & 29 & 28 \\
\hline \multirow{3}{*}{ KNMI [\%] } & 2025 & 45 & 76 & 21 & -16 & -18 & -24 & -8 & -8 & 28 & 30 & 9 & 33 \\
& 2055 & 90 & 110 & 32 & -9 & -10 & -19 & -30 & -18 & -1 & 23 & 1 & 50 \\
\hline & 2085 & 117 & 131 & 49 & -3 & -28 & -40 & -45 & -46 & -14 & 12 & 18 & 80 \\
\hline \multirow{3}{*}{ MPI [\%] } & 2025 & -3 & 29 & 12 & 6 & 7 & 10 & 24 & 7 & 32 & 28 & 11 & 7 \\
& 2055 & 44 & 87 & 25 & 8 & 7 & 3 & -5 & -20 & -11 & 10 & -1 & 25 \\
& 2085 & 87 & 103 & 36 & 10 & -5 & -14 & -19 & -34 & -17 & 38 & 28 & 62 \\
\hline
\end{tabular}

\section{CONCLUSIONS}

Considering the impact of land use change scenarios for the runoff processes, it can be concluded that the differences between the current land use and the several scenarios are minimal, but there may be several findings for this reason. Although the different components of the forests achieve similar parameter values, it cannot be expected that their changes will significantly affect runoff in this basin. It should also be noted that during the creation of the input maps of the land use scenarios, these areas that could not be categorized were replaced by the category of short grass. Another possible reason for the minimal impact of changes in the components of the forest on the runoff can be found in the size of the simulated river basins. These basins have a medium scale size. The differences in runoff may be minimized in the final profile. It turns out that with moderate changes in land use, there would be a better simulation of runoff on small catchment areas versus streams for this model. The WetSpa model could respond sensitively and with greater accuracy in this case.

Based on the scenarios of the long-term average discharges of future horizons and their comparison with the reference period of 1981 -2010 , it seems that in the future we can expect significant changes in the long-term mean monthly runoff in the simulated catchments. These changes may appear differently, depending on several climate change scenarios. The KNMI and MPI climate change scenarios represent less extreme changes (A1B emission scenario). The considered scenarios suggest that practically all the simulated basins could be at risk from summer or autumn droughts. Based on the simulated watershed in this work, it is likely that this effect will apply to the whole territory of Slovakia. On the other hand, it is possible that the runoff will increase in the winter. The lack of water stored as snowpack in the winter could affect the availability of water for the rest of the year.

The results of the simulation are highly dependent on the availability of the input data, the parameterization of the land use, the different types of vegetation in the model, and the schematization of the simulated processes; therefore, they need to be interpreted with a sufficient degree of caution and confronted with other results from the literature and experimental measurements.

\section{Acknowledgments}

This work was supported by the Slovak Research and Development Agency under Contract No. APVV 0303 - 11. The authors thank 


\section{REFERENCES}

Blahušiaková, A. - Matoušková, M. (2015) Rainfall and runoff regime trends in mountain catchments (Case study area: the upper Hron basin, Slovakia) J. Hydrol. Hydromech., Vol. 63, No. 3, 183-192, doi: 10.1515/johh-2015-0030.

Calder, IR. (2007) Forests and water-ensuring forest benefits outweigh water costs. Forest Ecology and Management 25: 110-120.

Hlavčová, K. - Szolgay - J., Kohnová, S. - Papánková, Z. - Horvát, O. (2005) On the possibility of assessment of land use change impact on runoff with a hydrological model with distributed parameters. Meteorological Journal, 8, 73-81.

Holko, L. - Hlavčo, J. - Danko, M. - Kostka, Z. (2014) Spatial Variability of Precipitation and Hydrological Response of a Mountain Catchment. In Journal for Management, Food and Environment : Die Bodenkultur - Austrian Journal of Agricultural Research, 2014, vol. 65, heft 3-4, pp. 15-21. (2014 - SCOPUS). ISSN 0006-5471.

Kostka, Z. - Holko, L. (2001) Runoff modelling in a mountain catchment with conspicuous relief using TOPMODEL. J. Hydrol. Hydromech., 49, 3-4, 149-171.

Lapin, M. - Faško, P. - Melo, M. - Št’astný, P. - Tomlain, J. (2002) Klimatické oblasti (Climatic regions). In: Zat'ko, M. (ed.), Atlas krajiny Slovenskej republiky, IV. Prvotná krajinná štruktúra (Primary landscape structure). MŽP SR a SAŽP, p. 95.

Lapin M. - Bašták I. - Gera M. - Hrvol’ J.- Kremler M. - Melo M. (2012) New climate change scenarios for Slovakia based on global and regional general circulation models. Acta Meteorologica Universitatis Comenianae, vol. 37, pp. 25 -73.

Lin, K. - Guo, S. - Zhang, W. and Liu, P. (2007) A new baseflow separation method based on analytical solutions of the Horton infiltration capacity curve. Hydrological Processes, vol. 21, no. 13, pp. 1719-1736.

Lin, K. - Zhang, Q. - Chen, X. (2010) An evaluation of impacts of DEM resolution and parameter correlation on TOPMODEL modeling uncertainty. Journal of Hydrology, vol. 394, nos. 3-4, pp. 370-383.

Maglocký, Š. (2002) Potenciálna prirodzená vegetácia (Potential natural vegetation). In: Zat'ko, M. (Ed.), Atlas krajiny Slovenskej republiky, IV. Prvotná krajinná štruktúra (Primary landscape structure). MŽP SR a SAŽP, pp.114-115.
Mind'aš, J. - Škvarenina, J. (2002) Lesné spoločenstvá a globálna klimatická zmena (Forest associations and global climate change). In Altas krajiny Slovenskej republiky, XI. Stresové javy $\mathrm{v}$ krajine (Stress phenomena in a landscape), MŽP SR a SAŽP, p. 95 .

Olivera, F. - Maidment, D. (1999) Geographic Information Systems (GIS)-Based Spatially Distributed Model for Runoff Routing. Water Resources Research 35(4):1155-1164.

Poórová, J. - Velčická, L. - Kuníková, E. - de Smedt, F. - Bahremand, A. - Corluy, J. - Liu, Y-B. (2005) Assessing impact of land use on floods using the WetSpa model. J. Hydrol. Hydromech., 53, 4, 253-266.

Rončák, P. - Hlavčová, K. (2015) Estimation of the effect of changes in forest associations on runoff processes in basins. Catchment Processes in Regional Hydrology: Linking experiments and modelling in Carpathian drainage basins [CD-ROM] / Catchment Processes in Regional Hydrology. - Sopron : University of West Hungary Press, 2015. - ISBN 978-963-334-268-8. - CD-ROM, [8] s.

Rosenzweig C. - Casassa G. - Karoly D. J. - Imeson A. - Liu C. Menzel A. - Rawlins S. - Root T. L. - Seguin B. - Tryjjanowski P. - Hanson C. E. (2007) Assessment of observed changes and responses in natural managed systems. In Contribution of Working Group II to the Fourth Assessment Report of the Intergovernmental Panel on Climate Change, Climate Change 2007: impacts, adaptation and vulnerability. Cambridge University Press: Cambridge, UK.

Škvarenina, J. - Mind'aš, J. - Čaboun, V. (1996) Lesné ekosystémy a globálne klimatické zmeny (Forest ecosystems and global climate change). Zborník referátov z medzinárodného seminára, Zvolen: Lesnícky výskumný ústav, 178 pp.

Wang Z. - Batelaan, O. - de Smedt, F. (1996) A Distributed Model for Water and Energy Transfer between Soil, Plants and the Atmosphere (WetSpa). Phys. Chem. Earth, 21(3): 189-193, Willmott. 